\title{
Contrasting Historical and Recent Breakup Styles on the Meade River of Arctic Alaska in the Context of a Warming Climate
}

\author{
Richard A. Beck ${ }^{1 *}$, Kenneth M. Hinkel ${ }^{1}$, Wendy R. Eisner ${ }^{1}$, Douglas Whiteman ${ }^{2}$, \\ Christopher D. Arp ${ }^{3}$, Richard Machida ${ }^{4}$, Chris Cuomo ${ }^{5}$, Hongxing Liu ${ }^{1}$, Changjoo Kim¹, \\ Andrew J. Rettig ${ }^{1}$, Chantal Ivenso ${ }^{1}$, Bo Yang ${ }^{1}$, Qiusheng Wu ${ }^{1}$, Haibin Su ${ }^{6}$, \\ Shujie Wang ${ }^{1}$, Karen Frey ${ }^{7}$, John D. Lenters ${ }^{8,9}$, Brittany L. Potter ${ }^{8}$ \\ ${ }^{1}$ Department of Geography, University of Cincinnati, Cincinnati, USA \\ ${ }^{2}$ Atmospheric Radiation Measurement Program, Atqasuk, USA \\ ${ }^{3}$ Water and Environmental Research Center, University of Alaska, Fairbanks, USA \\ ${ }^{4}$ Information Technology, University of Alaska at Fairbanks, Fairbanks, USA \\ ${ }^{5}$ Department of Philosophy, University of Georgia, Athens, USA \\ ${ }^{6}$ Department of Physics and Geosciences, Texas A\&M University-Kingsville, Kingsville, USA \\ ${ }^{7}$ Department of Geography, Clark University, Worcester, USA \\ ${ }^{8}$ School of Natural Resources, University of Nebraska at Lincoln, Lincoln, USA \\ ${ }^{9}$ LimnoTech, Ann Arbor, USA \\ Email: ${ }^{*}$ richard.beck@uc.edu
}

Received January 12, 2013; revised February 15, 2013; accepted February 25, 2013

Copyright (C) 2013 Richard A. Beck et al. This is an open access article distributed under the Creative Commons Attribution License, which permits unrestricted use, distribution, and reproduction in any medium, provided the original work is properly cited.

\begin{abstract}
Although data for temporal spring river ice breakup are available for a number of Arctic rivers, there is a paucity of information related to the type of breakup. The Arctic Climate Impact Assessment (ACIA) of 2005 predicted a transition from mechanical to thermal spring breakup of ice cover on arctic rivers, with this shift being greatest in exclusively Arctic watersheds where observed warming is most pronounced. We describe a rare instance of an entirely Arctic river with limited but well documented historical and recent data regarding the type of breakup. Time-series ground imagery of spring breakup from 1966, 1975, 1978, 2009, 2010 and 2012, in combination with interviews of local inhabitants, documents a shift from predominantly mechanical to predominantly thermal breakup after spring 1978 and by spring 2009 within the context of a locally and regionally warming Arctic. The resultant shift from predominantly mechanical to predominantly thermal breakup is predicted to result in significant changes to water, sediment, nutrient and organic carbon fluxes, as well as riparian ecology and human activities.
\end{abstract}

Keywords: Arctic; Alaska; Climate Change; Meade River; Thermal Breakup; Mechanical Breakup; Ice; Snow

\section{Introduction}

Spring breakup of arctic river ice typically occurs during the spring thaw and represents the most important hydrological event of the year in terms of freshwater, nutrient and sediment fluxes [1-4]. Spring breakup of surface river ice usually falls between two end members, mechanical and thermal [5]. Mechanical breakup consists of fracturing of the river's winter ice cover of the river and the transport of ice blocks downstream either continuously or intermittently via the formation and destruction of a series of ice jams. Mechanical breakup is usu-

${ }^{*}$ Corresponding author. ally relatively sudden and may be due to thaw and/or runoff in the headwaters of the river that increases the river's stage. The rising waters float and fracture downstream regions of ice cover. Abundant ice blocks associated with mechanical breakup often form ice jams that flood the adjacent riverbanks until the jam fails and the effects cascade further downstream [4]. Mechanical breakup has been common on north-flowing rivers in the Arctic because their headwaters often experience earlier thaw and runoff or rainfall while their more northerly downstream reaches are still ice covered [5]. In contrast, thermal breakup consists of gradual melting and thinning of the river ice cover due to warmer air temperatures 
above and/or warmer water temperatures below, dislodgement of the relatively thinner ice cover, fewer and weaker ice jams, less catastrophic ice jam failure, reduced scour and sediment and nutrient fluxes and a generally less destructive hydrologic regime [6-8].

\section{River Breakup in a Warming Arctic}

\subsection{Previous Observations on Arctic River Breakup}

A general warming trend throughout the Arctic for the last several decades has been cited as a reason for earlier breakup of river ice in Siberia [9] and northern Canada [10] with good agreement between ground and spacebased observations [11]. River breakup dates have advanced approximately 5.8 days per 100 years since 1846 with an increase in interannual variability since 1950 [12]. Smith [9] alluded to a potential trend from mechanical to thermal breakup on Siberian river between 1917 and 1994. Against this background of changing date and perhaps type of breakup, Peterson et al. found an increase in the discharge of arctic rivers to the Arctic Ocean of 7\% between 1936 and 1999 that could, in combination with Greenland ice cap melting, inhibit the formation of North Atlantic Deep Water and thermohaline ocean circulation [13].

\subsection{Predictions Regarding Arctic River Breakup in a Warming Climate}

The Arctic Climate Impact Assessment (ACIA) of 2005 [14] predicted a transition from mechanical to thermal spring breakup of ice cover on arctic rivers with increasing mean annual surface temperatures and significant changes to water, sediment, nutrient and organic carbon fluxes, riparian ecology and human activities. The ACIA also noted that available documentation of past changes was largely limited to simple observations of the timing of freeze-up and breakup. In addition, ACIA predicted that such changes would be greatest in exclusively arctic watersheds where observed warming is greatest. These predictions and their importance were reemphasized in the Snow, Water, Ice and Permafrost in the Arctic (SWIPA) report of 2011 [15]. Here we present evidence that this predicted shift from mechanical to thermal breakup is indeed occurring on at least one entirely arctic, south-to-north flowing river.

\section{Method and Rationale}

Although long-term records of river ice phenology and short-term process-based studies have certainly been conducted for parts of the subarctic [5] and for major rivers that flow from the subarctic to the Arctic [5,9], few data exist regarding the type of breakup (mechanical vs. thermal) on rivers with watersheds entirely within the Arctic Circle [14]. One rare exception is the time-series photographic study of the process of river ice breakup at Atqasuk on the Meade River (Kuulugruaq) of arctic Alaska during the spring of 1966 [16] (Figure 1).

In order to examine the process of spring breakup on the Meade River at Atqasuk on the central North Slope of Alaska (Figure 2) in the context of the 1966 study as well as interviews with local inhabitants that described a much more violent mechanical process of spring river breakup in the past [17], we established an automated camera system approximately $1.6 \mathrm{~km}$ north (downstream) of the 1966 study site that successfully captured timeseries ground imagery of spring breakup of 2009 [18] for comparison.

\section{Results}

The spring 2009 ground imagery showed a breakup process much closer to the thermal end member than the mechanical end member for river breakup as described by Beltaos [5,18]. Here we present new time-series ground imagery for 2010 and 2012 and a statistical analysis of long-term meteorological data for the Atqasuk, Alaska region that indicate a contrast between

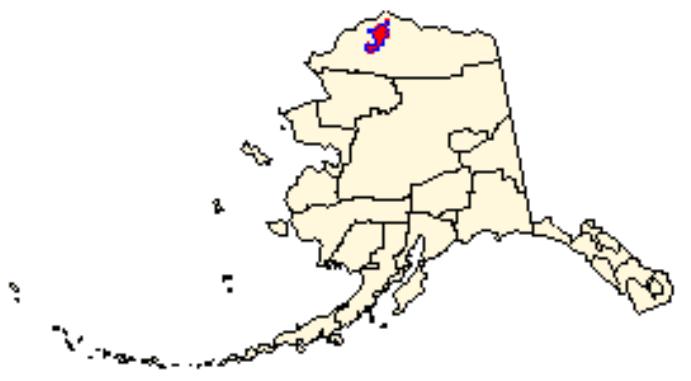

Figure 1. Location of Meade River watershed in Arctic Alaska. Courtesy USGS.

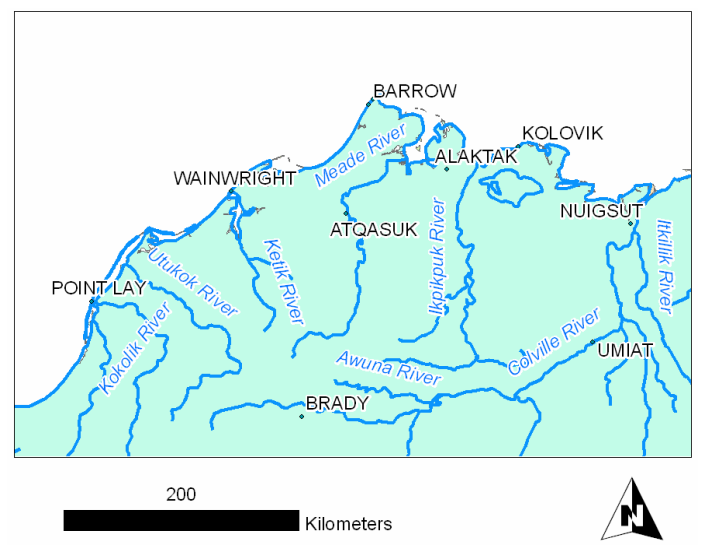

Figure 2. Map of the Meade River on the North Slope of Arctic Alaska with location of Atqasuk, and Umiat river breakup observation sites. 
predominantly mechanical breakup in the 1940s through 1970s (Figure 3) and predominantly thermal breakup since 2009 (Figure 4) on this entirely arctic river in the context of a locally and regionally warming Arctic. Breakup may also be occurring somewhat earlier (Figures 3 and 4 ).

The earliest published account of spring breakup on
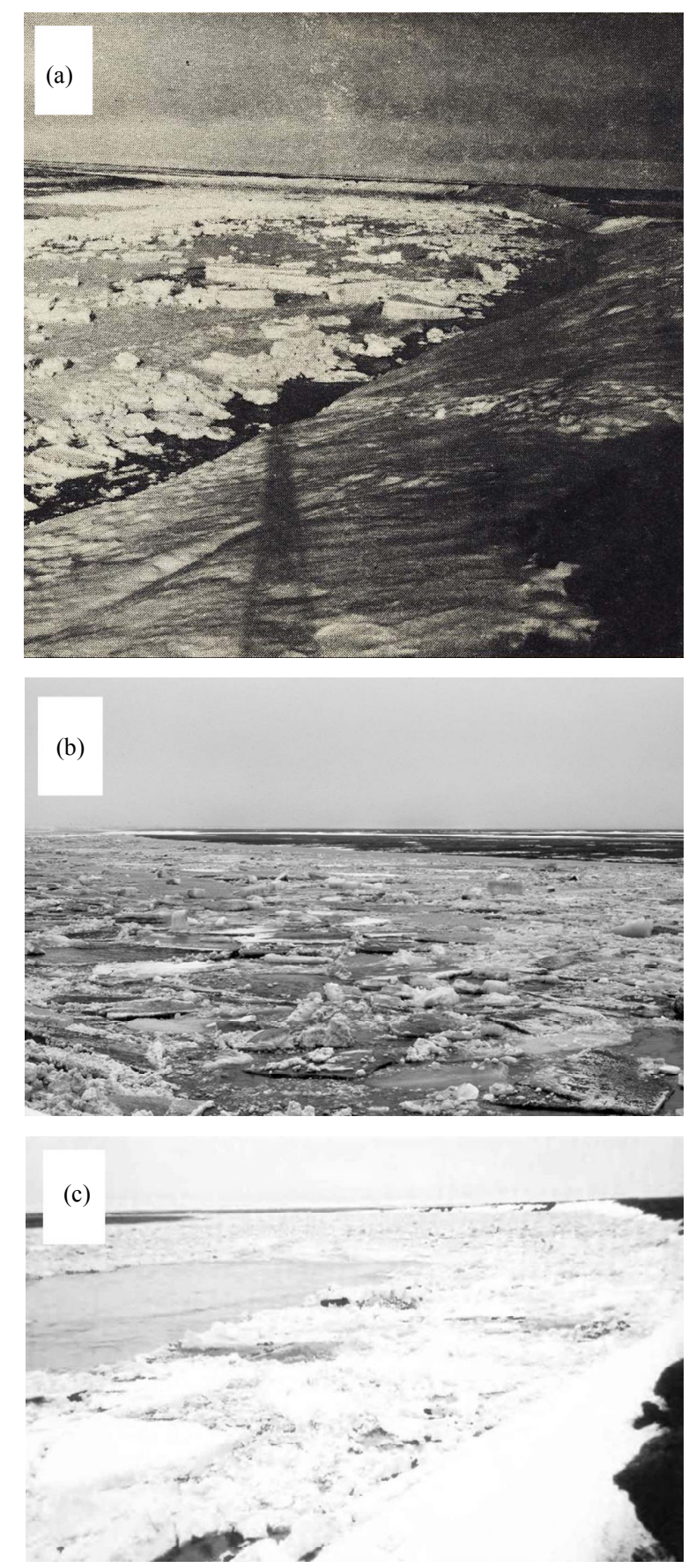

Figure 3. (a) Images of predominantly mechanical spring breakup on the Meade River at Atqasuk on 07 June, 1966 (CRREL), (b) 13 June, 1975 (T. May) and (c) 07 June, 1978 (USGS). Significant ice jams occurred in all three years.
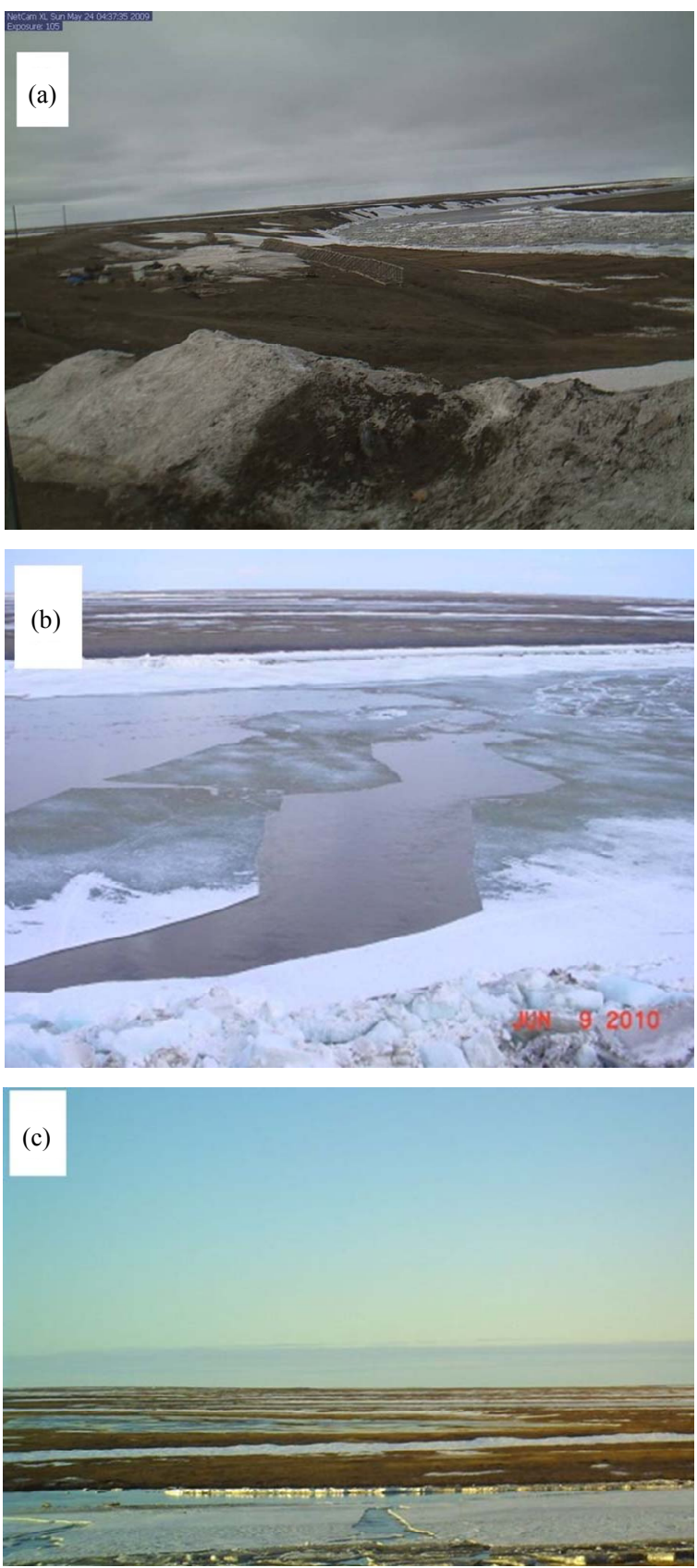

Figure 4. (a) Images of predominantly thermal spring breakup on the Meade River at Atqasuk on 24 May, 2009 (UC), (b) 09 June, 2010 (D. Whiteman) and (c) 02 June, 2012 (UC). No significant ice jams were observed in 2009, 2010, or 2012. No images are available from 2011.

the Meade River is from 1946 [19] when the US Navy lost 2 caches of petroleum exploration supplies during spring breakup at what is now Atqasuk due to the river rising 4.8 meters above normal river level [19] as a result of ice jams. Ground images from 1966, 1975, and 1978 indicate predominantly mechanical breakup until at least 1978 (Figure 3). Ground images from 2009, 2010, and 2012 indicate predominantly thermal breakup since at 
least 2009 (Figure 4) that corresponds to increasing average May surface air temperatures (Figure 5).

Local inhabitants also assert that breakup of the Meade River at Atqasuk has been predominantly of the thermal type (no major ice jams or ice jam related floods) for the last five to six years (since approximately 2006).

The ACIA prediction for a transition from mechanical to thermal breakup on arctic rivers is predicated on increasing spring temperatures [14] resulting in a longer "onset" (of melting) phase of breakup [5]. Indeed, average May surface air temperature measurements for Atqasuk from the USDA Natural Resources Conservation Service (NRCS) and NSF Circumpolar Active Layer Monitoring (CALM) meteorological station at Atqasuk show warming over the period from 1999-2011 (Figure 5).

Although there are no continuous or even nearly continuous meteorological measurements for the Meade River at Atqasuk before 1999, spatially averaged historical temperature data in the form of the NOAA NCEP/ NCAR Reanalysis [20] results for $70 \mathrm{~N}, 157 \mathrm{~W}(53 \mathrm{~km}$ SSE of Atqasuk) show warming of approximately $2^{\circ} \mathrm{C}$ for the period of $1948-2012$ and approximately $1.5^{\circ} \mathrm{C}$ for the period of 1966-2012 (Figure 5).

Statistical tests of 1948-2012 NOAA NCEP/NCAR May mean temperature data show that the data are not perfectly normally distributed with a skewness of 0.124

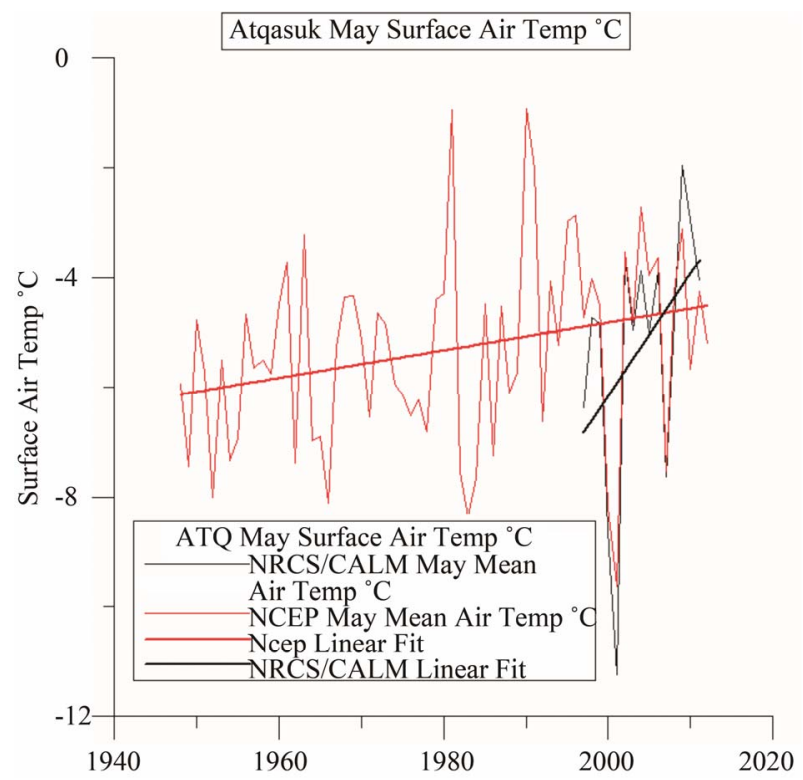

Figure 5. Measured USDA Natural Resources Conservation Service (NRCS) and NSF Circumpolar Active Layer Monitoring (CALM) May mean surface air temperature (black) and spatially averaged historical NOAA NCEP/NCAR Reanalysis results for $70^{\circ} \mathrm{N}, 157^{\circ} \mathrm{W}$ near Atqasuk (red) show warming of approximately $2^{\circ} \mathrm{C}$ for the period of 1948-2012. Both measured NRCS/CALM and spatially averaged NCEP/NCAR values show warming at Atqasuk on the Meade River. and a kurtosis of -0.076 . We began with a traditional non-parametric Spearman's R correlation test of time vs. temperature accordingly. The test resulted in a $p$ value of 0.008 and a Spearman's R statistic of 0.326 with 63 degrees of freedom. This test indicated that the time to temperature correlation was statistically significant.

We then applied a more rigorous Mann-Kendall twotailed time-series test [20] to the NOAA NCEP/NCAR data [21]. The resulting alpha value was 0.01 . The more rigorous Mann-Kendall test also indicates that the relationship is statistically significant. We conclude that warming from 1948 to 2012 near Atqasuk based on the NOAA NCEP/NCAR May mean temperature is statisticcally significant. The same test applied to 1966 to 2012 NOAA NCEP/NCAR May mean temperature results in an alpha value of 0.09 that is less than significant but just barely so. Similar tests on the more recent NRCS/CALM 1999-2011 [22] May mean temperature data show strong positive slopes but are not statistically significant due to the short record and high interannual variability.

The NOAA NCEP/NCAR reanalysis data show that May 1966 may have been anomalously cold although mechanical breakup was not unique to that year. T. May photographed spring breakup on the Meade River at Atqasuk (Figure 3(a)) on 13 June 1975 and documented severe ice jamming that is typically associated with mechanical breakup [23]. Jones (1977) noted that spring 1977 breakup flooding on the Colville and Meade Rivers was significantly increased by the presence of ice jams [24]. Similarly, Sloan (1978) described and photographed an ice jam on June 7, 1978 which "increased the stage and caused local overbank flow" [25]. The NOAA NCEP/NCAR reanalysis data show that May 1975, 1977, and 1978 were also cold, although not as cold as May 1966. We conclude that mechanical breakup was not uncommon in the $1960 \mathrm{~s}$ and $1970 \mathrm{~s}$ and corresponded with May mean temperatures that were generally colder than 2009-2012 (Figures 5 and 6).

Mean daily surface air temperatures for the Atqasuk area collected as part of the NSF Circumarctic Lake Observing Network (CALON) [20] at a location $16 \mathrm{~km}$ east of Atqasuk (named ATQ Lakes) for the last four years (2009-2012) all show marked seasonal warming between 10 and 20 May of each year (Figure 6).

Mean daily air temperatures fluctuated above and below the freezing threshold during the last two weeks of May 2009, 2011 and 2012 resulting in the extended "onset" phase [5] of breakup in 2009, 2010 and 2012 predicted by Prowse, Beltaos, ACIA and SWIPA $[4,14,15]$ as documented by our time-series ground imagery [18]. We do not have imagery from spring 2011 . The ACIA and SWIPA also predict a decreasing south to north surface air temperature gradient. Although we lack continuous historical measured meteorological data for sites 


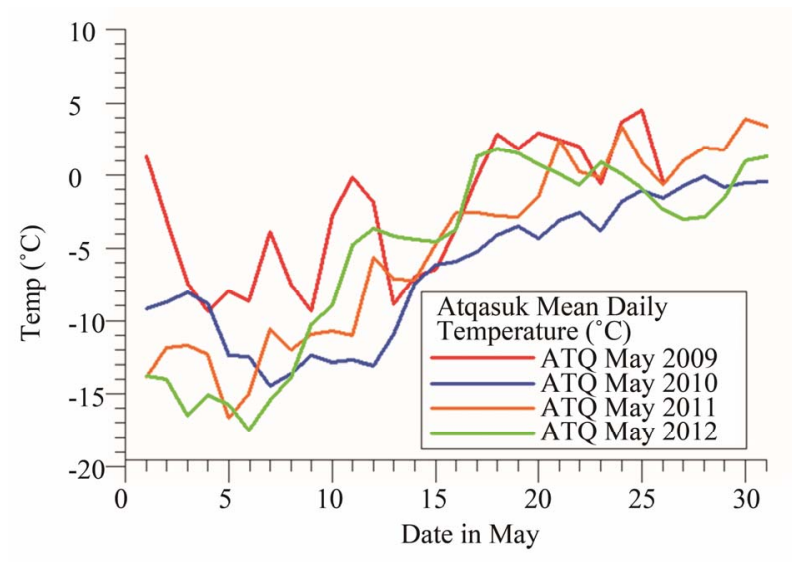

(a)

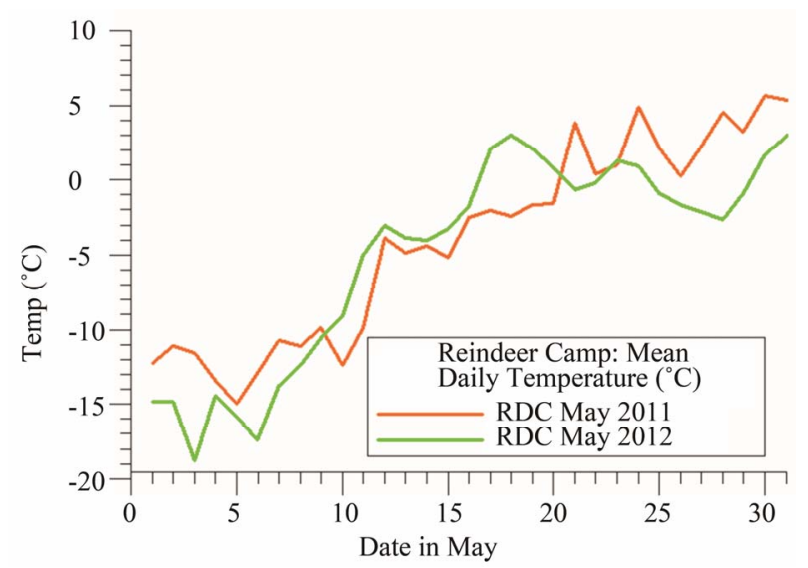

(b)

Figure 6. (a) Mean daily air temperature $\left({ }^{\circ} \mathrm{C}\right)$ data from the NSF CALON project for a site $16 \mathrm{~km}$ east of Atqasuk (ATQ lakes). (b) Mean daily air temperature data for a site $63 \mathrm{~km}$ SE of Atqasuk (RDC). Both sites warmed rapidly in midMay of 2009-2012 and 2011-2012 respectively.

in the northern Brooks Range south of Atqasuk, we have recently established a meteorological station named Reindeer Camp (RDC) at a location $63 \mathrm{~km} \mathrm{SE}$ of Atqasuk in the northern foothills of the Brooks Range (Figure 6).

Hourly air temperature data for ATQ and RDC show little if any south to north temperature gradient during spring breakup (Figure 7(a)) until later in June, presumably due to greater midsummer cloudiness in the foothills to the south as shown by lower solar radiation at the RDC site during the summer (Figure 7(b)) [22,23, 26].

Despite the lack of spring contrast in air temperature between ATQ and areas to the south, marked differences in spring surface air temperature persist between Atqasuk and points further north on the arctic coast due to the maritime effect of the Arctic Ocean [26,27] although that gradient appears to be decreasing slightly as predicted [26,27].

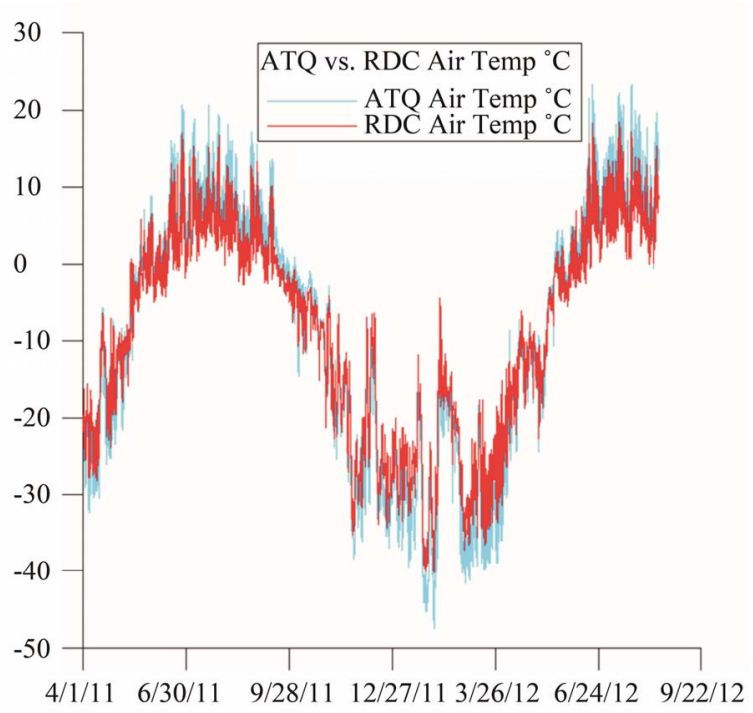

(a)

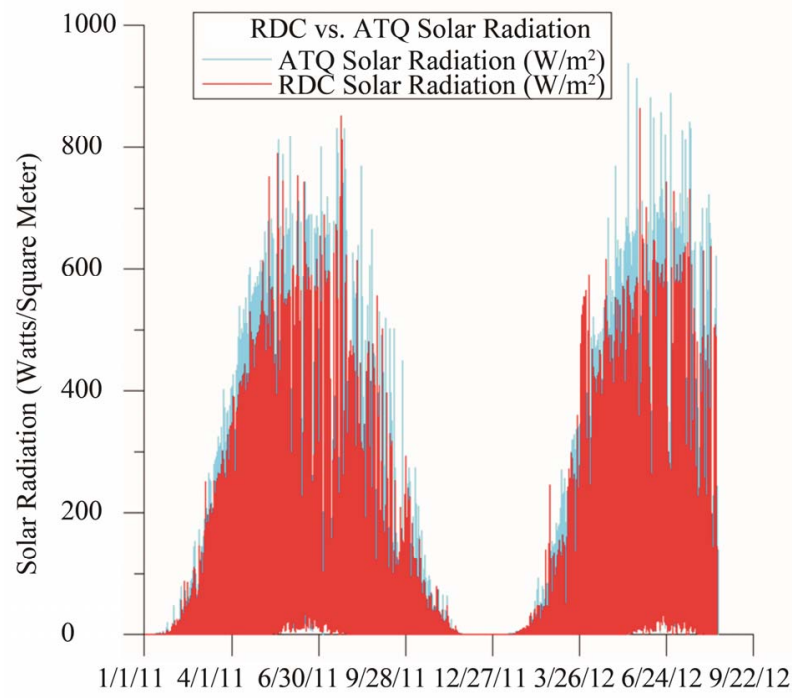

(b)

Figure 7. (a) Hourly air temperature $\left({ }^{\circ} \mathrm{C}\right)$ and (b) Mean hourly solar radiation $\left(\mathrm{W} / \mathrm{m}^{2}\right)$ for sites $16 \mathrm{~km}$ east (ATQ) and $63 \mathrm{~km}$ SE (RDC) of Atqasuk show minimal south to north air temperature gradients during May spring breakup of 2011 and 2012 from the NSF CALON project. Summer (winter) air temperatures are warmer (colder) at ATQ relative to $R D C$. Summer solar radiation is greater at ATQ, presumably due to summer cloud cover to the south in the foothills of the Brooks Range.

\section{Discussion}

Although there is a stream gage with a water and air temperature logger on the Meade River at Atqasuk, its data are listed as provisional and not for scientific use due to the difficulty of maintaining it at this remote site. A review of the last few years of gage data in the context of our time-series ground imagery and DOE and NSF meteorological data sets indicates that this caution is 
warranted. These gage data are not suitable for reconstructing either the timing or type of breakup.

Searches of the USGS Landsat and NASA ASTER archives for the Meade River watershed upstream of Atqasuk in order to reveal a historical record of the timing of breakup revealed too few cloud free images to create a meaningful record between 1966 and 2012 .

Searches of the NASA MODIS archive revealed enough cloud-free images to determine the degree of snow melt in the upper Meade River watershed, but the spatial resolution of MODIS is not sufficient to determine the timing of breakup much less the type of breakup on a river that is 50 - 150 meters wide in most places.

A larger number of Synthetic Aperture Radar (SAR) images are available that differentiate floating and grounded ice reasonably well [28]. It may be possible to recognize mechanical breakup on SAR images due to high backscatter but it is difficult to differentiate between low backscatter thermal breakup and subsequent low backscatter ice free conditions. Therefore, if we had access to continuous high spatial resolution SAR imagery (we do not) we could probably recognize and reconstruct the timing of predominantly mechanical breakup events but it would be difficult to reconstruct the end of predominantly thermal breakup events. We are currently working with the USGS and BLM to expand the number of time-series ground imagery stations on arctic rivers in northern Alaska in order to determine if the observed shift from predominantly mechanical to predominantly thermal breakup on the Meade River is a long-term trend.

Warming is a necessary precondition for the predicted transition from mechanical to thermal breakup $[6,7,14$, 15]. All available meteorological data support overall warming at Atqasuk over the last decade as well as the last 46 years. There are no published data regarding the type of breakup after 1978 and before 2009, but observations by local inhabitants support a recent shift from predominantly mechanical to predominantly thermal breakup on the entirely arctic Meade River at Atqasuk for the last "five to six years", probably after spring 2006. Although the timing of the shift is somewhat uncertain and the details of the process are as yet unknown, we can say with certainty that spring breakup in 2009, 2010 and 2012 was predominantly of the thermal type and contrasts strongly with the type of breakup documented in 1946, 1966, 1975, 1977 and 1978 [16,18] as predicted by the authors of the Arctic Climate Impact Assessment of 2005.

\section{Conclusions}

This apparent shift in type of breakup on the Meade River is coincident with a locally as well as regionally warming Arctic [14], the six lowest minimum arctic sea ice extents since 1979 (2007-2012) [29,30], record high permafrost temperatures in northern Alaska (2008-2012) [31], rapid thinning of lake ice in northern Alaska since 2003 [32], and record low May and June snow cover extents in the North American Arctic for three of the last five years (2007-2012) [33]. Profound changes to arctic hydrologic, ecological and socio-economic systems are expected if this apparent shift in the type of arctic river breakup continues and expands [34].

Observations of other North Slope Rivers such as the Colville at Umiat by the BLM, USGS and the authors indicate that breakup on those rivers is still predominantly mechanical. We suspect that the relatively small size and south-north flow of the Meade River simplify its hydrology and allow it to display thermal breakup more easily. Continued observations of the type of breakup on arctic rivers will be necessary to determine if the Meade River is merely an outlier or the harbinger of a consistent and long-term trend.

\section{Acknowledgements}

This work was supported by funding from the National Science Foundation under grants ARC-0640371 to RAB, OPP-9911122 and 0240174 to WRE, and OPP-9732051 and 0094769 and ARC-0713813 and 1107607 to KMH. Any opinions, findings, conclusions, or recommendations expressed in this material are those of the authors and do not necessarily represent the views of the $\mathrm{Na}$ tional Science Foundation. Any use of trade, product, or firm names is for descriptive purposes only and does not imply endorsement by the US Government. Dr. Terry A. May of Michigan State University generously supplied the photograph and a detailed written account of mechanical spring breakup in 1975. We are grateful for the logistical support of the Atqasuk Village Corporation, Barrow Arctic Science Consortium (BASC), the Ukpeagvik Inupiat Corporation (UIC) and $\mathrm{CH} 2 \mathrm{M}$ Hill Polar Services (CPS).

\section{REFERENCES}

[1] M. Church, "Hydrology and Permafrost with Reference to Northern North America," Permafrost Hydrology, Proceedings of the Workshop Seminar, Canadian National Committee, International Hydrological Decade, Ottawa, Vol. 7, 1974, pp. 7-20.

[2] G. D. Ashton, "River Ice," Annual Reviews of Fluid Mechanics, Vol. 10, 1985, pp. 369-392. doi:10.1146/annurev.fl.10.010178.002101

[3] T. D. Prowse, "The Environmental Significance of Ice to Cold Regions Stream Flow," Freshwater Biology, Vol. 32, No. 2, 1994, pp. 241-259. doi:10.1111/j.1365-2427.1994.tb01124.x

[4] T. D. Prowse and S. Beltaos, "Climatic Control of River-Ice Hydrology: A Review," Hydrological Processes, Vol. 16, No. 4, 2002, pp. 805-822. 


\section{doi:10.1002/hyp.369}

[5] S. Beltaos, "Threshold between Mechanical and Thermal Breakup of River Ice Cover," Cold Regions Science and Technology, Vol. 37, No. 1, 2003, pp. 1-13. doi:10.1016/S0165-232X(03)00010-7

[6] S. Beltaos and B. C. Burrell, "Climate Change and River Ice Breakup," Canadian Journal of Civil Engineering, Vol. 30, No. 1, 2003, pp. 145-155. doi:10.1139/102-042

[7] S. Beltaos and T. D. Prowse, "River-Ice Hydrology in a Shrinking Cryosphere," Hydrological Processes, Vol. 23, No. 1, 2009, pp. 122-144. doi:10.1002/hyp.7165

[8] T. D. Prowse and J. M. Culp, "Ice Breakup: A Neglected Factor in River Ecology," Canadian Journal of Civil Engineering, Vol. 30, No. 1, 2003, pp. 128-144. doi:10.1139/102-040

[9] L.C. Smith, "Trends in Russian Arctic River-Ice Formation and Breakup, 1917 to 1994," Physical Geography, Vol. 21, 2000, pp. 46-56.

[10] L. P. de Rham, T. D. Prowse and B. Bonsal, "Temporal Variations in River-Ice Breakup over the Mackenzie River Basin," Journal of Hydrology, Vol. 349, No. 3-4, 2008, pp. 441-454. doi:10.1016/i.jhydrol.2007.11.018

[11] T. M. Pavelsky and L. C. Smith, "Spatial and Temporal Patterns in Arctic River Ice Breakup Observed with MODIS and AVHRR Time Series," Remote Sensing of the Environment, Vol. 93, No. 3, 2004, pp. 328-338. doi:10.1016/j.rse.2004.07.018

[12] J. J. Magnuson, D. M. Robertson, R. H. Wynne, B. J. Benson, D. M. Livingstone, T. Arai, R. A. Assel, R. D. Barry, V. Card, E. Kuusisto, N. G. Granin, T. D. Prowse, K. M. Stewart and V. S.Vuglinski, "Historical Trends in Lake and River Ice Cover in the Northern Hemisphere," Science, Vol. 289, No. 5485, 2000, pp. 1743-1746. doi:10.1126/science.289.5485.1743

[13] B. J. Peterson, R. M. Holmes, J. W. McClelland, C. J. Vorosmarty, R. B. Lammers, A. I. Shiklamanov, I. A. Shiklamonov and S. Rahmstorf, "Increasing River Discharge to the Arctic Ocean," Science, Vol. 298, No. 5601, 2002, pp. 2171-2173. doi:10.1126/science. 1077445

[14] J. E. Walsh, et al., "Arctic Climate Impact AssessmentCryosphere and Hydrology," Vol. 6, The University of Alaska, Fairbanks, 2005, pp. 183-242.

[15] T. D. Prowse, et al., "Snow, Water, Ice and Permafrost in the Arctic (SWIPA)-Changing Lake and River Ice Regimes: Trends, Effects and Implications," Report by the Arctic Monitoring and Assessment Programme (AMAP) to the Arctic Council, AMAP Secretariat, Oslo, Norway, 2011, pp. 1-51.

[16] P. L. Johnson and F. B. Kistner, "Breakup of Ice, Meade River, Alaska," US Army Cold Regions Research Engineering Laboratory Special Report, Vol. 118, 1967, pp. $1-17$.

[17] W. R. Eisner, C. J. Cuomo, K. M. Hinkel, B. M. Jones and R. H. Brower, "Advancing Landscape Change Research through the Incorporation of Inupiaq Knowledge," Arctic, Vol. 62, No. 4, 2009, pp. 429-442.

[18] R. A. Beck, A. J. Rettig, C. Ivenso, W. R. Eisner, K. M. Hinkel, B. M. Jones, C. D. Arp, G. Grosse and D. White- man, "Sikuliqiruq: Ice Dynamics of the Meade RiverArctic Alaska, from Freeze-Up to Breakup from TimeSeries Ground Imagery," Polar Geography, Vol. 33, No. 3-4, 2010, pp. 115-137. doi:10.1080/1088937X.2010.545753

[19] J. C. Reed, "Exploration of Naval Petroleum Reserve No. 4 and Adjacent Areas Northern Alaska, 1944-1953-Part 1, History of the Exploration," USGS Professional Paper No. 301 , p. 55.

[20] D. R. Helsel and R. M. Hirsch, "Statistical Methods in Water Resources, Chapter A3, Book 4, Hydrologic Analysis and Interpretation," Techniques of Water-Resources Investigations of the United States Geological Survey.

[21] E. Kalnay, et al., "The NCEP/NCAR 40-Year Reanalysis Project," Bulletin American Meteorological Society, Vol. 77, No. 3, 1996, pp. 437-471. doi:10.1175/1520-0477(1996)077<0437:TNYRP $>2.0 . C O$ ;2

[22] K. M. Hinkel, et al., "Initial Results from the Circumarctic Lakes Observation Network (CALON) Project," American Geophysical Union, Fall Meeting, Abs. C21B0466, 2011.

[23] R. K. Haugen, J. Brown and T. A. May, "Climatic and Soil Temperature Observations at Atkasook on the Meade River, Alaska, Summer 1975," US Army Cold Regions Research and Engineering Laboratory Special Report Number 76-1, 1976, pp. 1-25.

[24] S. H. Jones, "Streamflow in the NPRA, 1977," USGS Alaska Accomplishments during 1977, USGS Circular 772-B, 1978, p. B-29.

[25] R. W. Paulson, E. B. Chase and R. S. Roberts, "National Water Summary 1988-1989-Floods and Droughts: Alaska," USGS Water-Supply Paper 2375, 1991, p. 175.

[26] R. K. Haugen and J. Brown, "Coastal-Inland Distributions of Summer Air Temperature and Precipitation in Northern Alaska," Arctic Alpine Research, Vol. 12, No. 4, 1980, pp. 403-412. doi:10.2307/1550491

[27] K. M. Hinkel, Z. Lin, Y. Sheng and E. A. Lyons, "Spatial Patterns of Lake Ice Melt Out near Barrow, Alaska," Polar Geography, Vol. 35, No. 1, 2012, pp. 1-18. doi:10.1080/1088937X.2011.654355

[28] N. Kozlenko and M. O. Jeffries, "Baythymetric Mapping of Shallow Water in Thaw Lakes on the North Slope of Alaska with Spaceborne Imaging Radar," Arctic, Vol. 53, No. 3, 2000, pp. 306-316.

[29] J. Maslanik, J. Stroeve, C. Fowler and W. Emery, "Distribution and Trends in Arctic Sea Ice Age through Spring 2011," Geophysical Research Letters, Vol. 38, No. 13, 2011, Article ID: L13502. doi:10.1029/2011GL047735

[30] D. Perovich, W., Meier, M. Tschudi, S. Gerland and J. Richter-Menge, "Sea Ice," Arctic Report Card: Update for 2012. NOAA, 2012. http://www.arctic.noaa.gov/reportcard/sea_ice.html

[31] V. E. Romanovsky, et al., "Permafrost," Arctic Report Card: Update for 2012. NOAA, 2012. http://www.arctic.noaa.gov/reportcard/sea_ice.html

[32] C. Arp, B. M. Jones, Z. Lu and M. S. Whitman, "Shifting 
Balance of Thermokarst Lake Ice Regimes across the Arctic Coastal Plain of Northern Alaska," Geophysical Research Letters, Vol. 39, No. 16, 2012, Article ID: L16503. doi:10.1029/2012GL052518

[33] C. Derksen and R. Brown, "Spring Snow Cover Extent Reductions in the 2008-2012 Period Exceeding Climate
Model Projections," Geophysical Research Letters, Vol. 39, No. 19, 2012, Article ID: L19504. doi:10.1029/2012GL053387

[34] T. Prowse, et al., "Effects of Changes in Arctic Lake and River Ice," AMBIO, Vol. 40, No. 1, 2011, pp. 63-74. doi:10.1007/s13280-011-0217-6 